\title{
Where does food fit in tourism?
}

Kuan-Huei Lee

$\mathrm{PhD}$ Candidate

School of Tourism, Faulty of Business, Economics \& Law

The University of Queensland, Brisbane QLD 4072, Australia

Tel: 61733460682

Fax: 61733468716

Email: kuan.lee@uqconnect.edu.au

Noel Scott

Associate Professor

Email: noel.scott@uq.edu.au

Jan Packer

Senior Research Fellow

Email: j.packer@uq.edu.au

\begin{abstract}
Definitions of food tourism (and related topics such as gastronomic tourism) explicitly mention food as an important or primary motivational factor for travel of tourists with interest in food. We present results from a qualitative study to support the need to separate travel motivation from motivation to undertake destination activities when studying food related travel. Members of the Slow Food organisation who are highly interested in food were interviewed. Results indicate this group did not choose their destinations primary because of food despite their strong interest, but did undertake food related activities in their destination. This study further suggests there is a need to revise the current definitions of food tourism and this special interest group of food and gastronomic tourists might identify a more restricted market segment than otherwise thought.
\end{abstract}

Keywords: food tourism; motivation to travel; Slow Food; destination management

Academic studies examining travel to destinations with a culinary appeal find a significant relationship between the food image of a place and the intention to visit (Ab Karim \& Chi, 2010; 
Frochot, 2003; Hjalager \& Corigliano, 2000). Food is recognised as an important factor in a tourist's experience of a destination (Henderson, 2009; Horng, Liu, Chou, \& Tsai, 2012), leading to marketing efforts by many governments to attract this special interest group (Hirst, Tresidder, \& Ebooks, 2012; Ignatov \& Smith, 2006; Sánchez-Cañizares \& López-Guzmán, 2012).

A number of definitions related to food tourism suggest that food is an important motivational factor for tourists to travel to a particular destination (Boniface, 2003; Hall, 2003; Henderson, 2004; Kivela \& Crotts, 2005). On the other hand, a study by McKercher, Okumus, and Okumus (2008) suggests that many studies of food tourism are not methodologically sound and calls for further research into food tourism motivation. McKercher et al. (2008) suggests past food tourism studies only examined the activities of tourists in the destination and so could only draw tenuous causal relationships between action (eating food) and motives (travelling for food); since eating food is a ubiquitous activity that everyone engages in at any destination, this method then cannot demonstrate a causal relationship between trip purpose and activities of tourists. Furthermore, the decision to undertake destination activities, including those related to food, might be decided after arrival at the destination (McKercher \& Chan, 2005).

A review of definitions of food-related tourism reveals two different views of the relative importance of food (or wine) as a motivation to travel to a particular destination. The definitions in Table 1 all consider the food of a particular location is an important and even primary motivating factor for the tourist to travel. The exception is the wine tourism definition of Brown and Getz (2005) which noted that the desire to participate in a wine related activity might not necessarily be a prime reason to travel to a destination. In the other definitions, it appears that decision to travel for food is considered an important reason for selecting travel destinations. Thus, the motivation of food tourists to travel to the destination is generally considered to be significantly influenced by the desire to savour local food and this is embedded in the relevant definitions (Table 1). However, the decision to undertake destination activities such as participation in a local food event might not be a consideration when tourists make their decision to travel (McKercher \& Chan, 2005; Smith, Pitts, \& Litvin, 2012). Therefore, there is some disagreement as when food becomes an important or primary motivational factor in tourists' decision making.

[Insert Table 1] 
Definitions of food tourism shown in Table 1, indicate these tourists possess high interest in food and are motivated to travel by it. The present study interviewed members of the Slow Food movement to assess whether this group are primarily influenced by food when they make their travel decisions. The Slow Food organisation is a non-profit foundation with over 20 years of history, and with over 100,000 members in 150 countries around the world. The philosophy of Slow Food is based on acquiring good, clean, and fair food: food should be tasty, varied, produced to maximise its flavour, and with connections to a geographic and cultural region; it should help to preserve rather than destroy the environment; and it should be produced in socially sustainable ways, with an emphasis on social justice and fair wages (Schneider, 2008). Food is an important component of Slow Food members' lifestyle, and members practice the Slow Food philosophy in their daily lives. Based on the view prevailing in definitions of food tourism, it may therefore be expected that Slow Food members' vacation travel would be somehow motivated by their high interest in food.

A total 41 qualitative indepth interviews were conducted with 43 members of the Slow Food movement to discuss factors influencing their travel destination choices. As Slow Food is an international movement with members in 150 countries around the world, this study selected 10 to 11 participants by first contacting a Slow Food convivium (chapter) leader in five selected regions (Australia, Argentina, Taiwan, Hong Kong and Italy). The purpose was to obtain rich information about Slow Food values, motivation to travel, and destination activity preferences. Target countries/regions were chosen according to time, budget, accessibility and language ability of the authors. Slow Food members were selected using snowball sampling, contacting first the leader of the local convivium (chapter) and then members whose names were obtained by referral. Table 2 shows a list of members interviewed (a total of 22 females and 21 males). Most of members were over 40 years of age and the majority had been Slow Food members for over three years. Interviews were audio-recorded with the permission of the respondents, transcribed and translated into English by the authors. All data were managed using NVivo software. Transcripts were subject to content analysis and a number of themes identified.

Despite the multicultural background of interviewees, all Slow Food members shared similar values toward food. With regards to their travel motivation, results indicated that these Slow Food members were not necessarily attracted to a destination because of its food-related image or motivated to travel because of food. Table 2 shows a list of main travel motivations of each 
member. Respondents mentioned the reasons of their trips were mostly for business, language learning, visiting family or friends, decided by other parties or to participate in Slow Food events as representative member. Only one respondent travelled specifically to experience the food of a destination in a recent trip:

The last trip was to Hokkaido, Japan with my family, three of us. We decided the trip two weeks before the departure and booked the airline and hotel online. The main reason we chose this destination was because my son wanted to eat Hokkaido seafood. He is 15 years old (Female, early-40s).

\section{[Insert Table 2]}

When Slow Food members made travel decisions, food was not an important factor in their decision making. Other factors such as learning a language (5\%), visit friend and family (28\%), and work purposes $(35 \%)$ were more important. Although Slow Food members were not travelling for food, they undertook food-related activities in the destination. Despite differences in culture, age, gender and profession, all Slow Food members liked to eat local food, bought from small-scale producers, read restaurant menus, participated in local food events, and joined cooking classes when possible. Slow Food members mentioned:

Every time I travel I try local food, particularly street food (Male, Over 60).

I eat what local people are eating...I always stay a weekend and visit the local market, where producers show their fresh products, cheese...I love it (Female, Over 60).

The findings suggest two different travel decision stages for Slow Food members, a decision to travel to a destination and a decision to undertake activities in a destination (Smallman \& Moore, 2010). Food was not an influential factor when deciding on a travel destination. According current definitions of food tourism, these members should not be considered as food tourists. However, on arrival in a destination members wanted to undertake food related activities and participated in local food activities. The results presented here are from one group of food interests and need to be supported by further research. Other food interest groups such as vegetarians or vegans, who represent a significant group of international consumers could be investigated to identify whether they choose destinations based on accessibility to vegan food (Hoek, Luning, Stafleu, \& de Graaf, 
2004; Kansanen, 2013). Yudina and Fennell (2013) have applied ecofeminism theory to discuss consumption of animal meat highlighting the value laden nature of food choice and this is another area for further research.

The results of this study with a group of international Slow Food members suggest that they were not making their travel decisions because of food despite their high interest in food, but they undertook food related activities after arriving to the destination. Thus, it proposes a need to revise current definitions of food and gastronomic tourism that link the primary travel motivation to food in the destination. It is a recommendation to separate motivation to travel and the interest to participate in food-related events in the destination when it comes to the definition of food and gastronomic tourism. This is because the number of tourists who travel primary for food to a destination might be quite small and that promotion of food may improve the overall image of the destination but may not stimulate travel by itself, especially long-haul travellers. Of course, this group may be expected to be larger where travel is to a food event or other activities that are geographically close to home. It may be much smaller where international travel is involved and therefore the promotional efforts of various national tourism organisations may not attract large numbers of visitors from overseas. It may be that food activities of any significant scale are only possible in destinations where there are significant other attractions or reasons for visiting. We therefore recommend that definitions of food tourism better differentiate between the relatively small number of travellers whose travel is exclusively motivated by food and the large numbers of travellers who are motivated to food distinctive of the destination.

\section{References}

Ab Karim, S., \& Chi, C. G.-Q. (2010). Culinary Tourism as a Destination Attraction: An Empirical Examination of Destinations' Food Image. Journal of Hospitality Marketing \& Management, 19(6), 531-555.

Boniface, P. (2003). Tasting tourism: travelling for food and drink. Aldershot: Ashgate.

Brown, G., \& Getz, D. (2005). Linking Wine Preferences to the Choice of Wine Tourism Destinations. Journal of Travel Research, 43(3), 266-276.

Frochot, I. (2003). An Analysis of Regional Positioning and Its Associated Food Images in French Tourism Regional Brochures. Journal of Travel \& Tourism Marketing, 14(3), 77-96.

Hall, C. M. (2003). Food tourism around the world development, management, and markets. Oxford: Butterworth-Heinemann.

Hall, C. M., \& Mitchell, R. (2001). Wine and food tourism. In N. D. R. Derrett (Ed.), Special interest tourism (pp. 307-325). Australia: John Wiley.

Hall, C. M., \& Sharples, L. (2008). Food events, festivals and farmers' markets: An introduction. In C. M. Hall \& L. Sharples (Eds.), Food and wine festivals and events around the world: development, management and markets. Amsterdam: Elsevier/Butterworth-Heinemann. 
Henderson, J. C. (2004). Food as a Tourism Resource: A View from Singapore. Tourism Recreation Research, 29(3), 69-74.

Henderson, J. C. (2009). Food tourism reviewed. British Food Journal, 111(4), 317-326.

Hirst, C., Tresidder, R., \& Ebooks, C. (2012). Marketing in food, hospitality, tourism and events: a critical approach. Oxford: Goodfellow Pub. Ltd.

Hjalager, A.-M., \& Corigliano, M. A. (2000). Food for tourists-determinants of an image. International Journal of Tourism Research, 2(4), 281-293.

Hoek, A. C., Luning, P. A., Stafleu, A., \& de Graaf, C. (2004). Food-related lifestyle and health attitudes of Dutch vegetarians, non-vegetarian consumers of meat substitutes, and meat consumers. Appetite, 42(3), 265-272.

Horng, J.-S., Liu, C.-H., Chou, H.-Y., \& Tsai, C.-Y. (2012). Understanding the impact of culinary brand equity and destination familiarity on travel intentions. Tourism Management, 33(4), 815-824. doi: 10.1016/j.tourman.2011.09.004

Ignatov, E., \& Smith, S. (2006). Segmenting Canadian Culinary Tourists. Current Issues in Tourism, 9(3), 235-255.

Kansanen, I. (2013). Vegan travel-The way how vegan diet influences travel experience. (Bachelor), HAAGA-HELIA University of Applied Sciences, Finland.

Kivela, J., \& Crotts, J. C. (2005). Gastronomy Tourism: A Meaningful Travel Market Segment. Journal of Culinary Science \& Technology, 4(2/3), 39-55.

Long, L. (1998). Culinary Tourism. Southern Folklore, 55(3).

McKercher, B., \& Chan, A. (2005). How Special Is Special Interest Tourism? Journal of Travel Research, 44(1), 21-31.

McKercher, B., Okumus, F., \& Okumus, B. (2008). Food Tourism as a Variable Market Segment: It's all how you cook the numbers! Journal of Travel \& Tourism Marketing, 25(2), 137-148.

Sánchez-Cañizares, S. M., \& López-Guzmán, T. (2012). Gastronomy as a tourism resource: profile of the culinary tourist. Current Issues in Tourism, 15(3), 229-245.

Schneider, S. (2008). Good, Clean, Fair: The Rhetoric of the Slow Food Movement. College English, 70(4), 384-402.

Smallman, C., \& Moore, K. (2010). Process studies of tourists' decision-making Annals of Tourism Research, 37(2), 397-422. doi: 10.1016/j.annals.2009.10.014

Smith, W. W., Pitts, R. E., \& Litvin, S. W. (2012). Travel and leisure activity participation. Annals of Tourism Research, 39(4), 2207-2210. doi: 10.1016/j.annals.2012.07.008

Sparks, B., Bowen, J., \& Klag, S. (2003). Restaurants and the tourist market. International Journal of Contemporary Hospitality Management, 15(1), 6-13.

Yudina, O., \& Fennell, D. (2013). Ecofeminism in the Tourism Context: a Discussion of the Use of Other-than-human Animals as Food in Tourism. Tourism Recreation Rearch, 38(1), 55-69. 
Table 1. Definitions of food tourism

\begin{tabular}{|c|c|c|c|c|}
\hline \multirow[b]{2}{*}{$\begin{array}{c}\text { Author } \\
\text { (year)/page number }\end{array}$} & \multirow[b]{2}{*}{ Definition } & \multicolumn{3}{|c|}{ Travel Motivation } \\
\hline & & $\begin{array}{l}\text { Before } \\
\text { arrival }\end{array}$ & $\begin{array}{l}\text { After } \\
\text { arrival }\end{array}$ & $\begin{array}{l}\text { Unspec } \\
\text { ified }\end{array}$ \\
\hline $\begin{array}{l}\text { Kivela and Crotts } \\
(2005) \text { p.42 }\end{array}$ & $\begin{array}{l}\text { Gastronomy tourism: travelling for the purpose of } \\
\text { exploring and enjoying the destination's food and beverage } \\
\text { and to savour unique and memorable gastronomy } \\
\text { experiences. }\end{array}$ & $\bullet$ & & \\
\hline Long (1998) p.45 & $\begin{array}{l}\text { Culinary tourism: the materiality of food of a destination } \\
\text { that helps to ground the experience for tourists, helping them } \\
\text { to relate it to their everyday lives. }\end{array}$ & & & $\bullet$ \\
\hline $\begin{array}{l}\text { Hall and Mitchell } \\
\text { (2001) p.308 }\end{array}$ & $\begin{array}{l}\text { Food tourism: visitation to primary and secondary food } \\
\text { producers, food festivals, restaurants and specific locations } \\
\text { for which food tasting and/or experiencing the attributes of } \\
\text { specialist food production regions are the primary } \\
\text { motivating factor for travel. }\end{array}$ & $\bullet$ & & \\
\hline Boniface (2003) p.15 & $\begin{array}{l}\text { Tasting tourism: travelling for food and drink to a } \\
\text { destination. }\end{array}$ & $\bullet$ & & \\
\hline $\begin{array}{l}\text { Sparks, Bowen, and } \\
\text { Klag (2003) p.6 }\end{array}$ & $\begin{array}{l}\text { Restaurant tourism: the role of restaurant industry in the } \\
\text { tourism experience and destination choice. }\end{array}$ & & & $\bullet$ \\
\hline $\begin{array}{l}\text { Brown and Getz (2005) } \\
\text { p.266 }\end{array}$ & $\begin{array}{l}\text { Wine tourism: a form of special-interest travel based on the } \\
\text { desire to visit wine-producing regions or in which travellers } \\
\text { are induced to visit wine-production regions and wineries in } \\
\text { particular, while travelling for other reasons. }\end{array}$ & $\bullet$ & $\bullet$ & \\
\hline $\begin{array}{l}\text { Hall and Sharples } \\
\text { (2008) p.6 }\end{array}$ & $\begin{array}{l}\text { Gourmet tourism: tourists with high interest in food and } \\
\text { wine and their travelling motivation is primary the visit of } \\
\text { specific food event or farmers' market. All, or nearly all, } \\
\text { visitor activities are food related. }\end{array}$ & $\bullet$ & & \\
\hline
\end{tabular}


Table 2. List of interviewees

\begin{tabular}{|c|c|c|c|c|c|c|}
\hline No. & Gender & Age & Occupation & $\begin{array}{l}\text { No. of Year } \\
\text { in Slow Food }\end{array}$ & $\begin{array}{l}\text { Location of } \\
\text { Slow Food } \\
\text { Convivium }\end{array}$ & Travel Motivation/s \\
\hline 1. & $\mathrm{~F}$ & Over 60 & Retired & 1 & Australia & $\begin{array}{l}\text { Visit family members \& } \\
\text { friends }\end{array}$ \\
\hline 2. & $\mathrm{M}$ & Over 60 & Retired & 13 & Australia & Profession-driven \\
\hline 3. & $\mathrm{~F}$ & Over 60 & Retired & 3 & Australia & $\begin{array}{l}\text { Decision by family or } \\
\text { friends }\end{array}$ \\
\hline 4. & M & Mid-50s & Banker & 11 & Australia & $\begin{array}{l}\text { Visit friends, relaxation, } \\
\text { Slow Food event }\end{array}$ \\
\hline 5. & $\mathrm{~F}$ & Mid-50s & Teacher (primary) & 11 & Australia & $\begin{array}{l}\text { Visit friends, relaxation, } \\
\text { Slow Food event }\end{array}$ \\
\hline 6. & $\mathrm{M}$ & Early-50s & Tax agent & 10 & Australia & Culture-driven \\
\hline 7. & $\mathrm{~F}$ & Mid-40s & Chef & 6 & Australia & Visit friends, music-driven \\
\hline 8. & $\mathrm{~F}$ & Early-40s & Farmer & 4 & Australia & Profession-driven \\
\hline 9. & $\mathrm{M}$ & Over 60 & Retired & 9 & Australia & Love for Europe \\
\hline 10. & $\mathrm{M}$ & Over 60 & Writer/food critic & 5 & Australia & Profession-driven \\
\hline 11. & $\mathrm{~F}$ & Over 60 & Retired & 3 & Australia & Visit friends \\
\hline 12. & $\mathrm{~F}$ & Early-50s & Social worker & 6 & Italy & $\begin{array}{l}\text { Repeat travel to the same } \\
\text { place every year }\end{array}$ \\
\hline 13. & M & Over 60 & Retired & 25 & Italy & Culture-driven \\
\hline 14. & $\mathrm{M}$ & Early-30s & Slow Food staff & 6 & Italy & Language-driven \\
\hline 15. & $\mathrm{~F}$ & Late-20s & Slow Food staff & 5 & Italy & $\begin{array}{l}\text { Honey moon (culture- } \\
\text { driven) }\end{array}$ \\
\hline 16. & $\mathrm{M}$ & Early-30s & Slow Food staff & 4 & Italy & Family-driven \\
\hline 17. & $\mathrm{~F}$ & Early-30s & Slow Food staff & 1 & Italy & Language-driven \\
\hline 18. & $\mathrm{~F}$ & Mid-50s & Dentist & 10 & Italy & Explore new destinations \\
\hline 19. & $\mathrm{M}$ & Over 60 & Farmer & 4 & Italy & Profession-driven \\
\hline 20. & $\mathrm{~F}$ & Late-20s & Slow Food staff & 2 & Italy & Family-driven \\
\hline 21. & $\mathrm{M}$ & Over 60 & B\&B owner & 10 & Italy & Profession-driven \\
\hline 22. & $\mathrm{~F}$ & Late-20s & Slow Food staff & 2 & Italy & Visit friends \\
\hline 23. & M & Over 60 & Academic & 12 & Argentina & Profession-driven \\
\hline 24. & $\mathrm{~F}$ & Over 60 & Chef & 8 & Argentina & Profession-driven \\
\hline 25. & $\mathrm{~F}$ & Early-50s & $\begin{array}{l}\text { Food business } \\
\text { owner }\end{array}$ & 4 & Argentina & Relaxation \\
\hline 26. & $\mathrm{~F}$ & Mid-40s & Chef & 9 & Argentina & Visit friends \\
\hline 27. & $\mathrm{M}$ & Mid-30s & Chef & 10 & Argentina & $\begin{array}{l}\text { Visit family, profession- } \\
\text { driven }\end{array}$ \\
\hline 28. & M & Over 60 & Architect & 10 & Argentina & Profession-driven \\
\hline 29. & $\mathrm{M}$ & Mid-40s & Accountant & 4 & Argentina & Relaxation \\
\hline 30. & $\mathrm{~F}$ & Early-50s & Food dealer & 5 & Argentina & Profession-driven \\
\hline 31. & $\mathrm{M}$ & Mid-50s & Lawyer & 13 & Argentina & $\begin{array}{l}\text { Repeat travel to the same } \\
\text { place every year }\end{array}$ \\
\hline 32. & $\mathrm{~F}$ & Early-30s & $\begin{array}{l}\text { PhD student and } \\
\text { Lecturer }\end{array}$ & 5 & Argentina & $\begin{array}{l}\text { Relaxation, decision made } \\
\text { with friends }\end{array}$ \\
\hline 33. & $\mathrm{M}$ & Over 60 & Retired & 10 & Taiwan & Visit family \\
\hline 34. & $\mathrm{~F}$ & Over 60 & Retired & 10 & Taiwan & Visit family \\
\hline 35. & $\mathrm{~F}$ & Mid-40s & Food critic & 12 & Hong Kong & Profession-driven \\
\hline 36. & $\mathrm{~F}$ & Over 60 & $\begin{array}{l}\text { Food business } \\
\text { owner }\end{array}$ & 8 & Taiwan & Visit friends \\
\hline 37. & $\mathrm{~F}$ & Early-40s & $\begin{array}{l}\text { Director of a Food } \\
\text { Foundation } \\
\end{array}$ & 3 & Taiwan & Food \\
\hline 38. & $\mathrm{~F}$ & Over 60 & Academic & 8 & Taiwan & Profession-driven \\
\hline 39. & $\mathrm{M}$ & Mid-50s & $\begin{array}{l}\text { Gastronomic } \\
\text { consultant }\end{array}$ & 5 & Taiwan & Profession-driven \\
\hline 40. & $\mathrm{M}$ & Early-50s & Restaurant owner & 9 & Taiwan & Profession-driven \\
\hline 41. & $\mathrm{M}$ & Over 60 & Retired & 8 & Taiwan & Visit friends \& families \\
\hline
\end{tabular}




\begin{tabular}{|l|l|l|l|l|l|l|}
\hline 42. & M & Mid-40s & Chef & 3 & Taiwan & Profession-driven \\
\hline 43. & M & Mid-30s & Chef & 10 & Taiwan & Profession-driven \\
\hline
\end{tabular}

